\title{
Operating Site Infections at General Surgery Department of Gabriel Toure Training Hospital
}

\author{
Bakary Tientigui Dembélé1,2, Alhassane Traoré1,2, Adégné Togo, ${ }^{1,2}$, Lassana Kanté1,2, \\ Ibrahim Diakité2, Bourama Diarra², Amadou Traorée, Madiassa Konaté2, \\ Boubacar Karembé2, Yacaria Coulibaly,1,2, Mamby Keita1,2, Souleymane Diallo1,3, \\ Gangaly Diallo1,2 \\ ${ }^{1}$ Faculty of Medicine and Odonto-Stomatology, Bamako, Mali \\ ${ }^{2}$ Department of General Surgery, CHU Gabriel Touré, Bamako, Mali \\ ${ }^{3}$ Department of Biology and Laboratory, CHU Gabriel Touré, Bamako, Mali \\ Email: btdembele@gmail.com
}

Received 15 January 2015; accepted 8 February 2015; published 11 February 2015

Copyright (C) 2015 by authors and Scientific Research Publishing Inc.

This work is licensed under the Creative Commons Attribution International License (CC BY). http://creativecommons.org/licenses/by/4.0/

(c) (i) Open Access

\section{Abstract}

The operating site infections constitute the major postoperative issue in surgery. Our objectives were to determine the hospital frequency, the risk factors, the involved germs as well as the cost generated by the operating site infections. Method: Our three months prospective survey run from September the 1st to November the 30th 2013 has included all department patients being operated on and hospitalized. The criteria have been set by CDC d'Atlanta. Results: 374 files were involved, among them $229(61.2 \%)$ were emergencies and $145(38.8 \%)$ were scheduled. The average age was 41 (extremes 7 and 95 standard deviation 17.46), the sex ratio 1.67. The infective risk according to Altmeier has found $17.5 \%$ type $1,25.1 \%$ type $2,11.2 \%$ type 3 and $46.3 \%$ type 4 ; according to NNISS, 96 (25.7) were NNISS 0; 94 (51.9\%) NNISS 1; 80 (21.4\%) NNISS 2; and 4 (1.1\%) NNISS. In the Altmeier class I have not got antibiotic before infection signs appearances. Our overall rate of operating site infections was $7.9 \%$ (29 cases), with $24(82.8 \%)$ emergency cases. According to Altmeier's class of infective risk, the rate of operating site infections was $1.54 \%$ making 1 out of 65 type I patients; $4.3 \%$ making 4 out of 93 type II patients; 11.9\% making 5 out of 42 type III patients; $10.9 \%$ making 19 out of 174 type IV patients. According to NNISS, the infective risk has been assessed and was $2.08 \%$ for score 0 , we have got $8.25 \%$ score 1 , and $12.5 \%$ for score 2 , and 25\% for score 3. The bacteriology has been dominated by Escherichia coli (51.7), Proteus mirabilis (13.8), and Klebsiella pneumoniae (10.34). The germs have been resistant to the combination Amoxicillin-clavulanic Acid between $50 \%$ and $87 \%$ of cases. The most active antibiotics on the germs have been Cephalosporin, Polypeptides, and aminoglycosides. The hospital stay has been 
delayed to 12 days on average by operating site infections, making 2.5 times greater than those uninfected. The infection has increased the cost of management around 600 Euro.

\title{
Keywords
}

\author{
Infections, Operating Sites, Bamako
}

\section{Introduction}

Despite the mastery of surgical techniques, the complications are still occurring, mostly the infections [1].

An infection is deemed postoperative, when it occurs just after the procedure (30 days) or later (a year), and related to the procedure [2]. Many surveys have been carried out about hospital-borne infections.

In the US and Europe, $2 \%$ of surgeries develop an operating site infection.

In Africa various high rates of prevalence have been published [3].

In Senegal, a frequency of 5.3\% of operating site infection has been found in 2003 [4]; 8.6\% in Ivory Coast.

In Mali, a survey carried out in 2007 at pediatric surgery department of Gabriel TOURE training Hospital has found $4.9 \%$ [5] against $8.81 \%$ of postoperative infection in 2001 at the service of general surgery and pediatric surgery Gabriel TOURE training hospital and $8.3 \%$ in 2004 at the same service [6].

Our objectives were to determine the hospital frequency, the risk factors, the involved germs as well as the cost of operating site infection's management at the general surgery service of Gabriel TOURE training hospital.

\section{Methods}

Our prospective survey carried out over 3 months, from September the $1^{\text {st }} 2013$ to November the $30^{\text {th }} 2013$.

It has included all patients who had undergone a surgery and hospitalized at least for 3 days at the general surgery department of Gabriel TOURE training hospital, complying with CDC ATLANTA's standards, which has set some criteria to determine the hospital connection of the operating site infection [7].

The size of the sample has calculated according to the following formula:

$\mathrm{N}=4(\mathrm{PQ}) \mathrm{I}^{2}$

$\mathrm{P}=$ prior operating site infection frequency

$\mathrm{Q}=1-\mathrm{P}$

$\mathrm{I}=$ error risk.

A similar survey has been carried out at our service in 2001, the frequency has been $8.3 \%$, thus $\mathrm{P}=8.083$ and $\mathrm{I}=0.05$ (error risk $=5 \%$ ) so the sample size $\mathrm{N}$ will be 117 .

The identification of an operating site infection with clinical criteria: (temperature, local symptoms, pus leaking from the site or the drain, a spontaneous dehiscence of the wound) and biological criteria: (wound fluid culture or drain fluid culture is deemed positive if germs are isolated); is subject to a blood sample collection for bacteriological check up plus antibiogram.

We did an aseptic aspiration of the collections with a single-use syringe and a cotton-swab if the infected wound is less leaking.

The blood samples were introduced in soya tryptase broth and put under scrutiny. We monitor it every morning over a week.

The studied parameters have been (administrative data, clinical findings, biological findings, the preoperative diagnosis and treatment, The ASA score, the NNISS score, the surgery technique, the preoperative treatment, the number of people in the operating room).

And after the procedure: the clinical data of the post operative infection, the biological check up plus antibiogram findings; the antibacterial treatment, the cost related to the operating site infection (check up fees, medicines and hospital stay); and the hospitalization duration).

Then, we have carried out some data crossing to find out the impact of some parameters on the occurrence of the operating site infection (see comments).

The consent of patient was mandatory for ethical constraints of the survey.

The results have been analyzed on EPI INFO software version 6.04.C.FR; and the typing with WORD soft- 
ware 2007. The statistic tests used to compare our results were KHI 2, and a significant $\mathrm{P}<0.05$.

\section{Results}

We have included 374 files, among them 299 cases of emergency (61.2\%) and 145 cases 38.8\% non-emergency.

The average age 41 (extremes 7 and 95, standard deviation: 17.46), the sex ratio was 1.67. 73/373 (19.5\%) patients were ASA 1, 150/374 (40.1\%) patients were ASA2, and 151/374 (40.4\%) patients ASA3. The infection risk (scale of contamination) according to ALTEMEIR found (42/374) 11.2\% of type 1, 65/374 (17.4\%) of type 2, 94/374 (25.1\%) of type 3 and 175/374 (46.3\%) of type 4.

According to NNISS, 96 cases (25.7\%) were NNISS 0, 194 cases (51.9\%) NNISS 1, 80 cases (21.4\%) NNISS 2, and 4 cases $(1.1 \%)$ NNISS 3. The class 1 of ALTEMEIR have not had antibiotic before the appearance of infection signs.

Among the other risk factors, we found the average number of people operating at $5.7 \pm 1.24$ per patient (extremes 4 and 13). Anemia in 58 patients (15.5\%). The surgeon experience was under 10 years in 189 (50.7\%) patients, antibiotic prophylaxis in 159 (42.5\%) patients.

Our operating site infection global rate has been 7.8\% (29 cases), with 24 (82.2\%) emergency cases, 8/29 (27.6\%) of deep operating site infection and 21/29 (72.4\%) were shallow. According to the class of infection risk of ALTEMEIR, the operating site infection has been 1.54\% making 1 out of 65 patients for type 1, 4.3\% making 4 out of 93 patients for type 2; 11.9\% making 5 out 42 patients for type 3, 10.9\% making 19 out of 174 patients for type 4 . According to the NNISS score, the operating site infection rate has been evaluated, we found $2.08 \%$ for score $0,8.25 \%$ score 1 and $12.5 \%$ score 2 and $25 \%$ score 3 . The average delay of infection occurrence was $4.79 \pm 2.93$ days (extremes 2 and 15 days).

The bacteriologic findings has been dominated by E. coli in 15 (51.7\%) cases, Proteus mirabilis in 4 (13.8\%) cases and Klebsiella pneumoniae in 3 (10.34\%) cases, Staphylococcus aureus in 2 (6.89\%) cases, and Proteus vulgaris in 1 (3.45\%).

The germs have been resistant to Amoxicillin plus Clavulanic Acid association between 50\% and $87 \%$ cases.

The most active antibiotics on germs have been the cephaloporins, the Polypeptides, the Aminoglycosides.

The susceptibility of the 3 major germs to antibiotics is represented in Table 1.

The average duration of hospitalization has been $21.4 \pm 10.44$ days (extremes 8 and 49 days).

The hospital stay has been delayed by 12 days on average by operating site infection making 2.5 times longer than non-infected patients. We have recorded 3/29 (10.3\%) of fatality among patients with operating site infection, but the fatalities causes were rather the complications related to either the disease which prompted the hospitalization or the surgery (cancers, peritonitis).

The infection has increased the cost of the management by around 650 Euro.

\section{Comments}

Our operating site infection rate at 7.9\% remained high. However, it is statically different from those found in African set: Senegalese and Moroccan [4] [8] with P > 0.05. However, it is statically higher than those of developed countries, as argued by the French and American sets [9] [10] which vary from 0.9\% to 2.5\%. The operating site infection being of numerous factors can be due to an insufficient preparation of operated emergencypatients, the lack of rigor in aseptic measures and in antisepsis, the precarious state of technical materials of the operating room.

We have found no significant negative influence of age on operating site infection occurrence with $\mathrm{P}=0.2606$ and Chi $2=5.2706$.

Table 1. Susceptibility of the 3 major germs to antibiotics.

\begin{tabular}{|c|c|c|c|c|c|}
\hline Antibiotics/Germs & Ceftriaxone & Amoxilline + Acide clavulanique & Ciprofloxacine & Gentamycine & Colistine \\
\hline Escherichia coli & 87 & $13 \%$ & $33 \%$ & $87 \%$ & $93 \%$ \\
\hline Proteus mirabilis & $75 \%$ & $25 \%$ & $25 \%$ & $100 \%$ & - \\
\hline Klebsiella pneumoniae & $100 \%$ & $33 \%$ & $33 \%$ & $100 \%$ & $63 \%$ \\
\hline
\end{tabular}


We have found no significant difference between gender and operating site infection occurrence with $\mathrm{P}=$ 0.461 .

Unlikely, some others suggest that operating site infection is more common in females as they have more fat tissue than males [11].

We found a negative influence of ASA class on operating site infection with $P=0.032$, but we have noticed an influence of ALTEMEIR risk class on operating site infection with $\mathrm{P}=0.0366$ and Chi $2=8.51$.

We have also found a negative influence of NNISS score on operating site infection with $\mathrm{P}=0.0357$ with Chi $2=8.5644$.

The emergency is deemed as risk factor influencing the occurrence of operating site infection in the literature [6]. In our study the infection rate was higher in emergency-patients making $24 / 29$ against $5 / 29$ for scheduled patients with $\mathrm{P}=0.00241$, the difference may be linked to insufficient preparation of emergency-patients.

The delay of infection appearance varied between 5 - 10 days on average during different surveys. Our study is not different from those of others set [5] [6] [12].

This average delay of appearance could be due to the incubation time and the inflammatory process of the infection [13].

It is classically admitted that the preoperative hospitalization duration influences the operating site infection rate; in fact, that rate is often related to the seriousness of the disease. During the preoperative hospitalization, the skin and digestive tracts germs flora undergo some alterations as soon as the $3^{\text {rd }}$ and $4^{\text {th }}$ day of hospitalization [7].

As in the literature, we have noticed and increase in infection rate according to ALTEMEIR class [13].

Our results range in the interval defined by CDC of Atlanta: $<5 \%$ for class $1,<10 \%$ for class $2,<20 \%$ for class $3,>30 \%$ for class $4[7]$.

For class 1: any statistic difference has been found between our rate of operating site infection and that of other authors with $\mathrm{P}$ varying between 0.32 and 0.49 .

Unlikely, for the classes 2, 3, 4 our operating site infection rate was statistically different from those of other authors with $\mathrm{P}$ varying from 0.018 to 0.000 .

The statistic differences found could be due to the size of the sample that is higher than in developed countries. [12].

The NNISS score is of multiple factors it represents a better indicator of more complex risk, predicting with a better liability. The occurrence of operating site infection, in comparison with ALTEMEIR class alone, we have noticed an increase in operating site infection with regard to the NNISS score in various sets [5] [6] [14].

During our survey, we have only recorded a patient with score 3 which presented an infection.

For score 0, we have not found any statistic difference between our rate and that of other authors. Unlikely, for score 1, 2, and 3, we got a statistic difference between our rate and those of literature [12] [14] with P varying from 0.042 to 0.000 . That difference may be due to the size of the sample which is higher in some countries. [12] [14].

In general surgery service, in prior studies, the germs ecology has been dominated by Eschericha coli, Staphyllococcus aureus, Klebsiella pneumoniae, Pseudomonas aeroginosa, Enterococcus [5]. Our survey has found the same germs; that is in accordance with the data of literature [15] [16]. The nature of germs according to the authors is represented in Table 2.

The consequences of operating site infection have been of two kinds:

Table 2. The nature of germs according to the authors.

\begin{tabular}{|c|c|c|c|c|}
\hline Germs Authors & Effectif total & 1er Germe & 2ème Germe & 3ème Germe \\
\hline $\begin{array}{c}\text { LEPOUTRE } \\
\text { France } 2006 \text { [20] }\end{array}$ & 19731 & $\begin{array}{c}\text { Escherichia coli } \\
(23 \%)\end{array}$ & $\begin{array}{c}\text { Staphylococcus aureus } \\
(20 \%)\end{array}$ & $\begin{array}{c}\text { Pseudomonas aéroginosc } \\
(11 \%)\end{array}$ \\
\hline $\begin{array}{c}\text { MARRONI } \\
\text { Italie } 2004[21]\end{array}$ & 18 & $\begin{array}{c}\text { Staphylococcus aureus } \\
(16.67 \%)\end{array}$ & $\begin{array}{c}\text { Escherichia coli } \\
(16.67 \%)\end{array}$ & $\begin{array}{c}\text { Pseudomonas aéroginosc } \\
(11.1 \%)\end{array}$ \\
\hline $\begin{array}{c}\text { TOURE [6] } \\
\text { Chirurgie CHU GT } 2006\end{array}$ & 27 & $\begin{array}{c}\text { Escherichia coli } \\
(40.7 \%)\end{array}$ & $\begin{array}{c}\text { Klebsiella pneumoniae } \\
(14.8 \%)\end{array}$ & $\begin{array}{c}\text { Proteus mirabilis } \\
(14.8 \%)\end{array}$ \\
\hline $\begin{array}{c}\text { Notre étude } \\
\text { Chirurgie CHU GT } 2010\end{array}$ & 29 & $\begin{array}{c}\text { Escherichia coli } \\
(51.7 \%)\end{array}$ & $\begin{array}{l}\text { Proteus mirabilis } \\
(14.8 \%)\end{array}$ & $\begin{array}{c}\text { Klebsiella pneumoniae } \\
(10.3 \%)\end{array}$ \\
\hline
\end{tabular}


- Prolonged hospital stay:

The hospitalization duration has been delayed by 12 days for infected patients making 2.5 times longer than non-infected patients.

According to some authors, the delay is 16.6 days [17], and according to others, the delay is 21.4 days [18] that could be due to the bad condition of some patients and low economic background.

- Overspending linked to infection:

The infection has increased the cost of the management by around 650 Euro, making 15 times the minimum wage of Malian which is 43 Euro.

That extra-spending is related to the hospitalization cost, check-ups, antibiotics and bandage materials.

The mortality rate was $10.3 \%$. BAILY France in 2002 found a lower rate at $2.4 \% \mathrm{P}=0.00231$.

Some surveys carried out by some authors have got no direct connection between infection and mortality, but suggest that infection may be responsible of 3\% of fatalities [19]-[21].

The infection has not been the direct cause of any fatality.

The patients died from the complications of the diseases for which they have been hospitalized or operated on.

\section{Conclusions}

The operating sites infection at our service has been negatively influenced by the length of the procedure, the ASA class, the type of surgery, the inclusion mode (emergency) and the NNISS score.

With the prevention measures in our service, the operating site infection rate has slightly decreased, but despite being lower than those of other surveys carried out in Mali and in Africa, nevertheless it remains a regular issue in surgery.

\section{References}

[1] Bone, R.C., Balk, R.A., Cerra, F.B., Delinger, R.P., Fein, A.M., Knaus, W.A., et al. (1992) Definition of Sepsis and Organ Failure and Guidelines for the Use of Innovatrice Therapies in Sepsis. Chest, 101, 1644-1655. http://dx.doi.org/10.1378/chest.101.6.1644

[2] Paris-Nord, C. (1999) Le réseau INCISO trios mois de surveillance des infections du site opératoire dans 120 services de chirurgie de l'inter-region. Paris-nord. BEA, 25, 106-107 .

[3] Pilly, E. (1992) Maladie Infectieuse. Annal de Chirurgie, 417, 310-319.

[4] Chevalier, B., Saliou, C., Fall, R., Farthouat, P., Deconnink, J.P., et al. (2004) Surveillance des infections du site opératoire dans les services chirurgicaux de l’hôpital principal de Dakar. Xième Actualité du pharo, 66, 9-11.

[5] Togo, A., Coulibaly, Y., Dembélé, B.T., Togo, B., et al. (2011) Risk Factors for Surgical Site Infection in Children at the Teaching Hospital Gabriel Touré, Bamako. Journal of Hospital Infection, 79, 371-372. http://dx.doi.org/10.1016/j.jhin.2011.08.007

[6] Toure, L. (2004) Les infections du site opératoire dans le service de chirurgie générale et pédiatrique du CHU Gabriel Touré. Thèse de Médecine, Bamako, 57.

[7] CDC Atlanta (1990) Les infections nosocomiales: Recommandations en matière d'enregistrement des infections nosocomiales. ATLANTA OP, 1-10.

[8] Chadli, M., Rtabi, N., Alkandry, S., Koek, J.L., et al. (2005) Incidence des infections du site opératoire étude prospective à l'hopital militaire d'instruction Mohamed-V de Rabat, Maroc. Médecine et Maladies Infectieuses, 35, 218-222. http://dx.doi.org/10.1016/j.medmal.2005.03.007

[9] Elizabeth, F. (2002) Infection Nosocomiale. Revue du Praticien, 10, 1-3.

[10] Mekhail, N.A., Mathews, M., Nageeb, F., et al. (2007) Retrospective Review of 707 Cases of Spinal Cord Stimulation: Indication and Complications. Pain Practice, 11, 148-153. http://dx.doi.org/10.1111/j.1533-2500.2010.00407.x

[11] LENOUVAILLE Enquête épidémiologique sur les infections postopératoires à l'.hôpital de Orthily. Thèse de médecine, Bordereau 1985, 7.

[12] Astagneau, P. (2001) Infection du site opératoire; Réseau d'Alerte d’Investigation et de Surveillance des Infections Nosocomiales (RAISIN). Paris Journal of Hospital Infection, 48, 267-274.

[13] CCLIN SUD-EST (2008) Conseil pour la prévention du risque infectieux. CCLIN Sud-Est, 4.

[14] Medeiros, A.C., Aires-Neto, T., Azevedo, G.D., Vilar, M.J.P., Pinheiro, L.A.M. and Brandão-Neto, J. (2005) Surgical Site Infection in a University Hospital in Northeast Brazil. Brazilian Journal of Infectious Diseases, 9, 310-314. 
[15] Jupeau-Vessieres, A.H. and Scavizzi, M.R. (1995) Maladies Infectieuses. Encyclopédie Médico-Chirurgicale, 3, 7783.

[16] Anagonous, S.Y., Makoutode, M. and Amassoubdji, B. (1994) Sensibilité des antibiotiques d'Escherichia coli en milieu hospitalier à propos de 1468 souches isolées au centre hospitalier et universitaire de cotonou. Médecine d'Afrique noire, 13, 8-10.

[17] McGeer, A., Campbell, B., Emori, T.G., Hierholzer, W.J., Jackson, M.M., Nicolle, L.E., et al. (1991) Definitions of Infection for Surveillance in Long-Term Care Facilities. American Journal of Infection Control, 19, 1-7. http://dx.doi.org/10.1016/0196-6553(91)90154-5

[18] Beytout, D. (1989) Ecologie Microbienne. In: Le Minor, L. and Veron, M., Eds., Bactériologie Médicale, Ellipses, Paris, 478-479.

[19] Balagny, E. (1988) Surveillance générale, infimière-Anesthsit; D.A.R-Hôpital Saint Antoine 184, rue du Fg St Antoine 6ème journée anesthésie réa, Paris, 23-40.

[20] Lepoutre, A. (2001) Réseau d’Alerte d'Investigation et de surveillance des Infections Nosocomiales (RAISIN). Enquête nationale de prévalence, Institut de Veille Sanitaire, Saint-Maurice.

[21] Fiorio, M., Marroni, M., Tristaino, B., Capitanucci, L., Serafini, S., De Socio, G. and Stagni, G. (2004) Nosocomial Infections in a General Surgical Ward. Recenti Progressi in Medicina, 95, 11-14. 
Scientific Research Publishing (SCIRP) is one of the largest Open Access journal publishers. It is currently publishing more than 200 open access, online, peer-reviewed journals covering a wide range of academic disciplines. SCIRP serves the worldwide academic communities and contributes to the progress and application of science with its publication.

Other selected journals from SCIRP are listed as below. Submit your manuscript to us via either submit@scirp.org or Online Submission Portal.
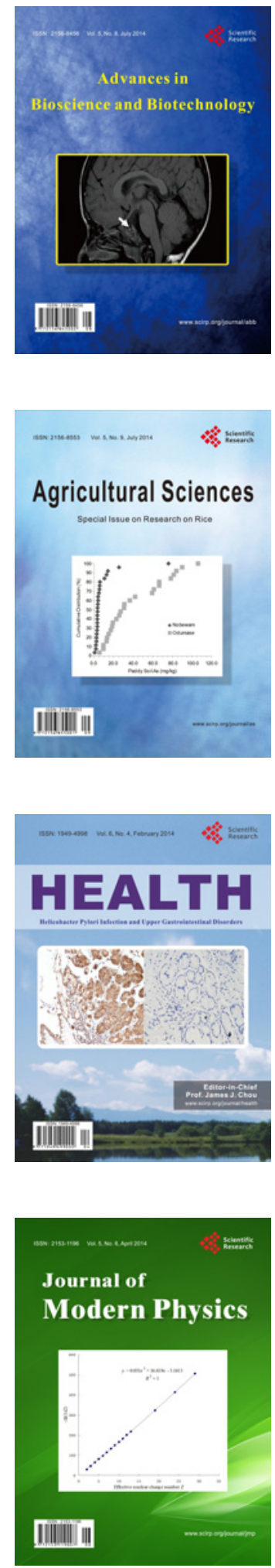
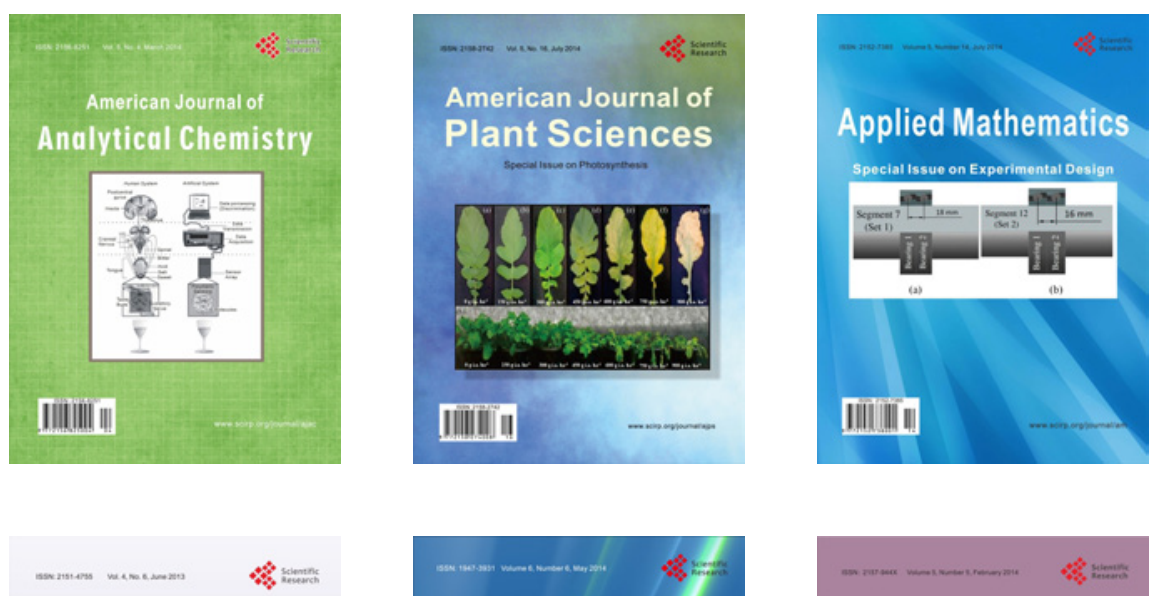

Creative Education
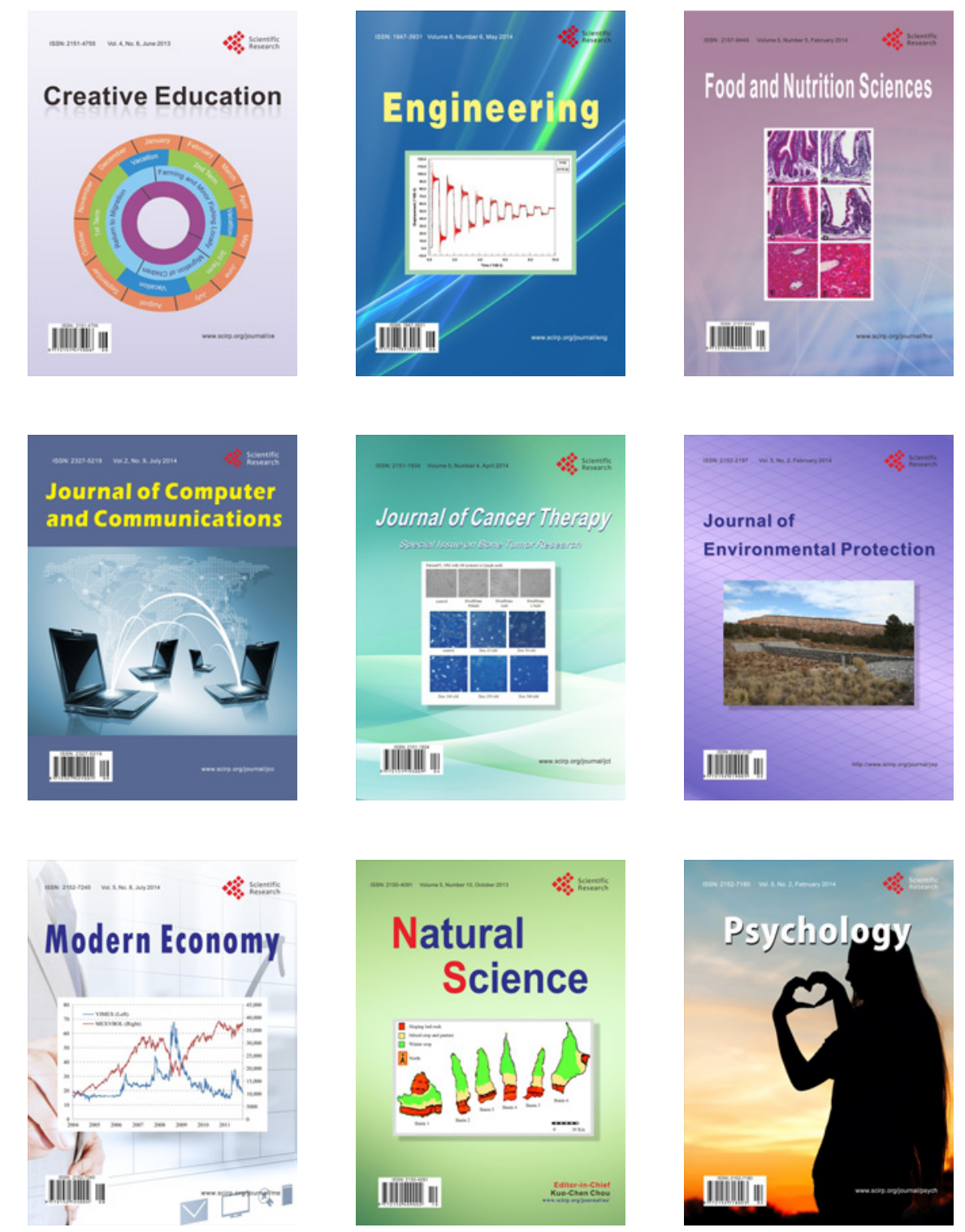